\title{
The Role of Carbonate in the Metabolism of Glucose by Butyrivibrio fibrisolvens
}

\author{
By B. D. W. JAR VIS \\ Department of Microbiology and Genetics, Massey University, \\ Palmerston North, New Zealand \\ C. HENDERSON \\ Microbiology Department, Rowett Research Institute, Bucksburn, Aberdeen AB2 9SB \\ AND R. V. ASMUNDSON \\ Department of Microbiology and Genetics, Massey University, \\ Palmerston North, New Zealand
}

(Received 14 October 1977; revised 21 November 1977)

The amount of $\mathrm{Na}_{2} \mathrm{CO}_{3}$ added to semi-synthetic medium determined the length of the lag phase, the growth rate and the dry weight of three strains of Butyrivibrio fibrisolvens (wv1, NOR37, $\mathrm{B} 835$ ). With increasing $\mathrm{CO}_{3}{ }^{2-}$ concentration the molar growth yield of bacteria, from glucose, was increased and, of the fermentation products, formate increased more than the other acids. $\mathrm{CO}_{3}{ }^{2-}$-limited cultures of strain wv1 (Group 2 Butyrivibrio) and strain NOR37 (Group 1 Butyrivibrio) incorporated ${ }^{14} \mathrm{CO}_{3}{ }^{2-}$ into lactate and formate. In NOR37, lactate and formate had equal specific activities; in wv1, the formate specific activity was twice that of lactate. Strain wvl had an active pyruvate synthase and an energy-dependent exchange between $\mathrm{CO}_{3}{ }^{2-}$ and formate was demonstrated. In strain wv1 butyrate was produced mainly from glucose.

\section{INTRODUCTION}

Many rumen bacteria require an exogenous source of $\mathrm{CO}_{2}$ for growth (Dehority, 1971). Butyrivibrio was originally described as a group which did not require exogenous $\mathrm{CO}_{2}$ (Bryant \& Small, 1956) but subsequently some strains were shown to require exogenous $\mathrm{CO}_{2}$ and others to be stimulated by it (Shane, Gouws \& Kistner, 1969; Dehority, 1971). Exogenous $\mathrm{CO}_{2}$ is used by rumen bacteria for the synthesis of cell material (Wright, 1960; Dehority, 1971) or may take part in reactions leading to metabolite formation (Caldwell, Keeney \& Van Soest, 1969; Miller \& Wolin, 1973; Howlett et al., 1976).

Shane et al. (1969) subdivided the genus Butyrivibrio into two groups differentiated by their nutritional requirements and cellobiose fermentation products. Briefly, Group 1 strains have simple nutritional requirements, utilize acetate and produce, in addition to butyrate, large amounts of lactate and small amounts of formate. Group 2 strains are nutritionally fastidious and produce acetate and butyrate with small amounts of lactate and large amounts of formate.

The large numbers of butyrivibrios found in rumen contents of roughage-fed animals (Caldwell \& Bryant, 1966; Van Gylswyk, 1970; Latham, Sutton \& Sharpe, 1974) suggest that this genus contributes a significant proportion of the microbial protein available to the animal and participates in the production of butyrate and the interconversion of acetate and butyrate (Latham \& Legakis, 1976; Van Gylswyk, 1976). Consequently the mechanisms 
of energy and end-product generation in the butyrivibrios are significant features of rumen metabolism which deserve further study.

Asmundson (1974) observed that the molar growth yield of Butyrivibrio fibrisolvens wv1 (a Group 2 strain) strongly depended on the amount of $\mathrm{CO}_{2}$ in the medium and that appreciable labelled carbon from ${ }^{14} \mathrm{CO}_{3}{ }^{2-}$ appeared in the volatile fatty acid fraction of the growth medium. This paper describes the effect of carbonate on the fermentation of glucose by strain wv1 and two other strains of $B$. fibrisolvens.

\section{METHODS}

Media. The semi-synthetic medium 10 of Caldwell \& Bryant (1966) was modified to the following composition $\left[\mathrm{g}(100 \mathrm{ml})^{-1}\right]$ : Trypticase (BBL), 0.2 ; yeast extract (Difco), 0.05 ; glucose, 0.1 ; cysteine, 0.025 ; resazurin, $0.00001 ; \mathrm{K}_{2} \mathrm{HPO}_{4}, 0.237 ; \mathrm{KH}_{2} \mathrm{PO}_{4}, 0.141 ; \mathrm{NaCl}, 0.004 ;\left(\mathrm{NH}_{4}\right)_{2} \mathrm{SO}_{4}, 0.045 ; \mathrm{MgSO}_{4} .7 \mathrm{H}_{2} 0,0.009$; $\mathrm{CaCl}_{2} .6 \mathrm{H}_{2} \mathrm{O}, 0.004 ; \mathrm{Na}_{2} \mathrm{CO}_{3}, 0 \cdot 16$. Trypticase and yeast extract were dissolved in water, resazurin, $\mathrm{KH}_{2} \mathrm{PO}_{4}$, $\mathrm{CaCl}_{2} \cdot 6 \mathrm{H}_{2} \mathrm{O}$ and the remaining minerals were added as separate solutions. This mixture was autoclaved at $121{ }^{\circ} \mathrm{C}$ for $15 \mathrm{~min}$ and cooled to $40^{\circ} \mathrm{C}$ under $\mathrm{O}_{2}$-free $\mathrm{CO}_{2}$. Concentrated solutions of $\mathrm{Na}_{2} \mathrm{CO}_{3}$, cysteine and glucose were sterilized by filtration and immediately added to the autoclaved, cooled medium, to produce the liquid medium A. This medium contained approximately $4 \mathrm{~mm}$-acetate, $0.7 \mathrm{~mm}$-propionate and $0.8 \mathrm{~mm}$-lactate which were present in the Trypticase and yeast extract as contaminants.

Solid medium for roll tubes and slopes was prepared by adding $2 \%(\mathrm{w} / \mathrm{v})$ agar to medium A before it was autoclaved.

For experiments on $\mathrm{CO}_{3}{ }^{2-}$ metabolism, liquid medium $\mathrm{A}$ without $\mathrm{Na}_{2} \mathrm{CO}_{3}$ was prepared and handled under $\mathrm{O}_{2}$-free $\mathrm{N}_{2}$ (medium $\mathrm{B}$ ). The required levels of $\mathrm{CO}_{3}{ }^{2-}$ were obtained by adding appropriate volumes of filter-sterilized $\mathrm{Na}_{2} \mathrm{CO}_{3}$ solution. Medium $\mathrm{B}$ minus glucose was used to wash bacteria free from carbonate.

Bacteria. Three strains of Butyrivibrio fibrisolvens were used: strain wv1 was isolated in New Zealand by Dr R. T. J. Clarke; strain NOR37 was isolated in Reading by Dr M. E. Sharpe; strain B835 was from the culture collection of the Rowett Research Institute. The purity of each strain was verified from colonial and morphological characteristics. Isolated colonies in roll tubes prepared from high dilutions of each culture were inoculated into liquid medium and incubated at $37^{\circ} \mathrm{C}$ for 24 to $48 \mathrm{~h}$, transferred to agar slopes, incubated for a further 24 to $48 \mathrm{~h}$ and then frozen at $-70^{\circ} \mathrm{C}$. These frozen slopes served as stock cultures. To prepare an inoculum, a stock culture was thawed and subcultured twice in $10 \mathrm{ml}$ of liquid medium under $100 \% \mathrm{CO}_{2}$. The second subculture was washed twice and resuspended in 3 to $5 \mathrm{ml}$ of anaerobic wash medium under $\mathrm{N}_{2}$. Inocula which became oxidized during preparation were discarded.

Cultural methods. The effect of $\mathrm{CO}_{3}{ }^{2-}$ on growth and metabolism was studied in culture vessels of 150 to $160 \mathrm{ml}$ capacity, consisting of a cylindrical body (approximately $35 \mathrm{~mm} \mathrm{diam}$.) with a short neck fused to one end and a cuvette fused to the other. These vessels were sterilized by autoclaving, cooled and flushed with $\mathrm{N}_{2}$ for 3 to 5 min before sterile pre-reduced medium was added. Medium $\mathrm{B}(37 \mathrm{ml})$, containing glucose, was transferred to the culture vessel with a $10 \mathrm{ml}$ syringe and the vessel was closed with a rubber stopper while a stream of $\mathrm{N}_{2}$ was entering it. All subsequent additions were made by syringe through the stopper. The different levels of $\mathrm{CO}_{3}{ }^{2-}$ required were obtained by adding $2.8 \mathrm{ml}$ of sterile aqueous solution containing various proportions of filter-sterilized $2 \cdot 12 \%(\mathrm{w} / \mathrm{v}) \mathrm{Na}_{2} \mathrm{CO}_{3}$ solution.

Completed medium was incubated for $24 \mathrm{~h}$ at $39^{\circ} \mathrm{C}$ to check sterility. The vessels were then inoculated by injecting $0 \cdot 1 \mathrm{ml}$ washed bacterial suspension. Each vessel was immediately mixed by inversion, sampled for assay of initial glucose concentration and then incubated in a water bath at $39^{\circ} \mathrm{C}$.

Analytical methods. Culture turbidity was measured in situ using an EEL colorimeter fitted with a dark blue filter ( 440 to $500 \mathrm{~nm}$ ). Bacterial dry wt was determined when turbidity measurements indicated that growth had ceased. The culture $(37 \mathrm{ml})$ was centrifuged at $20000 \mathrm{~g}$ for $20 \mathrm{~min}$ at $5^{\circ} \mathrm{C}$, the supernatant was removed for analysis and the pellet was washed with $10 \mathrm{ml}$ distilled water. The washings were discarded. The cells were transferred quantitatively to a weighed glass tube, recentrifuged at $9000 \mathrm{~g}$ for $50 \mathrm{~min}$ at room temperature and the pellet was dried overnight at $75^{\circ} \mathrm{C}$ then weighed.

Glucose was measured by the glucose oxidase method of Morley, Dawson \& Marks (1968). Acetate, propionate and butyrate were assayed by gas-liquid chromatography (Fell et al., 1968). The concentrations of volatile fatty acids were deduced from peak areas by comparison with standard curves. Formate was measured by the colorimetric method of Barker \& Somers (1966), ethanol by the enzymic method of Kaplan \& Ciotti (1957) and lactate by the microdiffusion method of Conway (1957).

Carbon dioxide was measured by the NaOH-trapping method of Dawes, McGill \& Midgley (1971). Their apparatus was adapted to deal with samples from culture vessels by attaching a test-tube fitted with a side arm to the gas inlet of the bead tower. The test-tube was closed by a rubber stopper bearing a 13 gauge needle 
which extended to the base of the tube. Samples $(2.0 \mathrm{ml})$ for analysis were injected through the stopper with a hypodermic syringe and $\mathrm{N}_{2}$ was bubbled through the needle into the sample at a rate of about 200 bubbles $\min ^{-1}$. The sample was acidified by injecting $1.0 \mathrm{ml} 0 \cdot 1 \mathrm{M}-\mathrm{HCl}$ and the $\mathrm{CO}_{2}$ was transferred quantitatively, by bubbling for $20 \mathrm{~min}$, to $10.0 \mathrm{ml} 0.01 \mathrm{M}-\mathrm{NaOH} . \mathrm{CO}_{2}$ was estimated by back titration using phenolphthalein indicator in the presence of $2.0 \mathrm{ml} 0.1 \mathrm{M}-\mathrm{BaCl}_{2}$. When radioactively labelled substrates were used, the suspension of $\mathrm{BaCO}_{3}$ was made up to $50.0 \mathrm{ml}$ and sampled for radioactivity measurements.

Preparation of silicic acid columns. The method used was based on that of Bové \& Raveux (1957). Silicic acid (4 g, 100 mesh, AR; Mallinckrodt, St Louis, U.S.A.) was mixed with $0.25 \mathrm{M}-\mathrm{H}_{2} \mathrm{SO}_{4}(1 \mathrm{ml})$ and shaken in an Erlenmeyer flask to disperse the $\mathrm{H}_{2} \mathrm{SO}_{4}$ through the silicic acid. The acid-treated powder was mixed with $25 \mathrm{ml}$ chloroform (washed with distilled water) and the suspension was poured into a glass column plugged at the lower end with lipid-free cotton wool. When the silicic acid had partially settled it was stabilized by eluting with a further $40 \mathrm{ml}$ chloroform. The samples of mixed fermentation acids were loaded after the chloroform had drained to the level of the silicic acid in the column.

Analysis of radioactivity in fermentation end-products. Samples $(2 \mathrm{ml})$ of bacteria-free culture media were made alkaline and evaporated to dryness. Each dry sample was acidified and transferred to a silicic acid column by Pasteur pipette. The sample tube was rinsed with chloroform and the chloroform was also added to the silicic acid column. The volatile fatty acids and lactic acid were separated by eluting the column sequentially with $25 \mathrm{ml}$ chloroform containing 4,8 or $15 \%(\mathrm{v} / \mathrm{v}) n$-butanol. Samples $(2 \mathrm{ml})$ of eluate were collected in polypropylene scintillation vials and titrated with $0.005 \mathrm{M}$-methanolic $\mathrm{NaOH}$, using phenol red as indicator. The neutralized samples were evaporated to dryness, and $0 \cdot 1 \mathrm{ml}$ water was added to redissolve the salts, followed by $10 \mathrm{ml}$ scintillation fluid.

Radioactivity counting. All samples were counted in scintillation fluid [toluene, 1 litre; Triton X-100, 0.5 litre; 2,5-diphenyloxazole (PPO), 3.0 g; and 1,4-di-2-(5-phenyloxazolyl)benzene (POPOP), 0.3 g] on a Packard Tri-carb liquid scintillation counter, making appropriate corrections for quenching.

Aqueous samples $(1.0 \mathrm{ml})$ were counted in $9.0 \mathrm{ml}$ scintillation fluid. Column eluate samples were made up to $0 \cdot 1 \mathrm{ml}$ and counted in $10 \mathrm{ml}$ scintillation fluid. Gas phase radioactivity was displaced by a slow stream of $\mathrm{N}_{2}$ and trapped in $18 \%(\mathrm{v} / \mathrm{v})$ ethanolamine; samples $(0.5 \mathrm{ml})$ of ethanolamine solution were diluted with an equal volume of water and made up to $10.0 \mathrm{ml}$ with scintillation fluid. Radioactivity incorporated in bacteria was measured in triplicate samples $(0.4 \mathrm{ml})$ of cell suspension which were collected and washed with distilled water $(3 \times 1 \mathrm{ml})$ on membrane filters $(0.22 \mu \mathrm{m})$; each filter was dried briefly at $75^{\circ} \mathrm{C}$ before being placed in $10 \mathrm{ml}$ scintillation fluid. When these methods were used to determine the distribution of radioactivity between liquid, vapour and cellular phases in duplicate glucose-labelled cultures of $B$. fibrisolvens, the sums of the counts recovered from the cultures were 94.3 and $101.8 \%$ of the counts added.

\section{RESULTS}

\section{Medium}

Preliminary experiments with B. fibrisolvens strain wv1 (Asmundson, 1974) in Caldwell \& Bryant (1966) medium containing 5.55 mm-glucose showed a marked response to addition of Trypticase up to $0.2 \%(\mathrm{w} / \mathrm{v})$ and a much smaller response above this level. Thus $0.2 \%$ Trypticase is sufficient to provide the organic nitrogen required in the medium.

In $0.2 \%$ Trypticase medium, glucose up to $20 \mathrm{~mm}$ was growth-limiting. As our medium routinely contained $5.55 \mathrm{~mm}$-glucose our results were obtained under conditions of energylimited growth.

The buffering capacity of Caldwell \& Bryant (1966) medium was inadequate when used to prepare $\mathrm{CO}_{3}{ }^{2-}$-limited cultures under $\mathrm{N}_{2}$ due to the decreased contribution of the $\mathrm{HCO}_{3}{ }^{-} /$ $\mathrm{CO}_{2}$ buffer system and the low concentrations of $\mathrm{PO}_{4}{ }^{3-}$. When strain wv1 was grown in

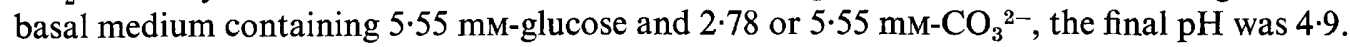
When the phosphate buffer concentration was increased to $24 \mathrm{mM}$ with $\mathrm{CO}_{3}{ }^{2-}$ concentrations of $0 \cdot 1,1 \cdot 11,2 \cdot 78,5 \cdot 55,22 \cdot 2,33 \cdot 3 \mathrm{~mm}$, the final $\mathrm{pH}$ values were $6 \cdot 8,6 \cdot 7,6 \cdot 4,6 \cdot 5,6 \cdot 8$, 6.8 respectively. Such changes in $\mathrm{pH}$ were considered unlikely to cause changes in glucose metabolism and the medium was used routinely with this buffer concentration.

\section{Effect of $\mathrm{CO}_{3}{ }^{2-}$ concentration on growth rate and bacterial yield}

Each strain of $B$. fibrisolvens used in this study required exogenous $\mathrm{CO}_{3}{ }^{2-}$. The lag phase, growth rates and molar growth yields of the three cultures were each proportional to the 
Table 1. Effect of $\mathrm{CO}_{3}{ }^{2-}$ concentration on growth rate and molar growth yield in B. fibrisolvens

\begin{tabular}{|c|c|c|c|}
\hline Strain & $\begin{array}{l}\mathrm{CO}_{3}{ }^{2-} \text { concn } \\
\text { (mM) }\end{array}$ & $\begin{array}{l}\text { Growth rate } \\
\qquad\left(\mathrm{h}^{-1}\right)\end{array}$ & $\begin{array}{c}\text { Yield } \\
{\left[\mathrm{g}(\mathrm{mol} \text { glucose })^{-1}\right]}\end{array}$ \\
\hline wv1 & $\begin{array}{r}1 \\
2 \\
4 \\
10 \\
14\end{array}$ & $\begin{array}{l}0.05 \\
0.19 \\
0.26 \\
0 \cdot 44 \\
0.38\end{array}$ & $\begin{array}{l}24 \cdot 0 \\
35 \cdot 0 \\
42 \cdot 0 \\
48 \cdot 0 \\
49 \cdot 0\end{array}$ \\
\hline B835 & $\begin{array}{r}1 \\
2 \\
4 \\
10 \\
14\end{array}$ & $\begin{array}{l}0.06 \\
0 \cdot 10 \\
0 \cdot 11 \\
0.09 \\
0.08\end{array}$ & $\begin{array}{c}\text { ND } \\
28 \cdot 5 \\
28 \cdot 6 \\
29 \cdot 0 \\
30 \cdot 0\end{array}$ \\
\hline NOR 37 & $\begin{array}{r}1 \\
2 \\
4 \\
10 \\
14\end{array}$ & $\begin{array}{l}0.08 \\
0.22 \\
0.44 \\
0.37 \\
0.47\end{array}$ & $\begin{array}{l}30 \cdot 0 \\
35 \cdot 0 \\
36 \cdot 0 \\
39 \cdot 0 \\
42 \cdot 0\end{array}$ \\
\hline
\end{tabular}

$\mathrm{CO}_{3}{ }^{2-}$ concentration (see Table 1). The requirement for $\mathrm{CO}_{3}{ }^{2-}$ by $\mathrm{B} 835^{\prime}$ was met at concentrations below those required by NOR37 and wv1.

\section{Retention of carbon from glucose and $\mathrm{CO}_{3}{ }^{2-}$}

Cultures were grown in anaerobic culture vessels on basal medium containing glucose (5.55 mM) and $\mathrm{CO}_{3}{ }^{2-}-(4.0 \mathrm{mM})$ under an atmosphere of $\mathrm{O}_{2}$-free $\mathrm{N}_{2}$ with [U-14 C]glucose or ${ }^{14} \mathrm{CO}_{3}{ }^{2-}$ being added before inoculation. Growth was terminated at the start of the stationary phase. When the distribution of ${ }^{14} \mathrm{C}$ was determined in the medium, in the gas phase and in the bacteria (Table 2), relatively little ${ }^{14} \mathrm{C}$ from ${ }^{14} \mathrm{CO}_{3}{ }^{2-}$ was found in the bacteria. With strain $\mathrm{wv} 1,{ }^{14} \mathrm{C}$ from $\left[{ }^{14} \mathrm{C}\right]$ glucose was mainly in the bacteria-free liquid phase.

Thus under these conditions $B$. fibrisolvens (wv1) metabolized most of the glucose to produce energy and little of it was used to form new cell material. Similarly, although $\mathrm{CO}_{3}{ }^{2-}$ was essential for growth, little of it was incorporated into cell carbon which suggested that $\mathrm{CO}_{3}{ }^{2-}$ might have a role in energy production by these bacteria.

\section{Effect of $\mathrm{CO}_{3}^{2-}$ limitation on glucose fermentation products}

Duplicate cultures of each of the three strains of $B$. fibrisolvens were grown to the beginning of the stationary phase in the anaerobic culture vessels on the glucose-limited basal medium containing six different $\mathrm{CO}_{3}{ }^{2-}$ levels ranging from 0 to $14 \mathrm{mM}$. The quantity of fermentation products formed with each organism (Fig. 1) was proportional to the glucose used and carbon balances indicated that an average of $89.6 \%$ of the glucose consumed was accounted for in the products measured. Each strain produced butyrate as a major fermentation product. NOR37 produced a relatively high proportion of lactate and a low proportion of formate even at the highest $\mathrm{CO}_{3}{ }^{2-}$ concentrations tested. Although it produced a little acetate, NOR37 conformed to Group 1 of Shane et al. (1969) since Latham \& Legakis (1976) showed that under certain conditions Group 1 strains can produce small amounts of acetate instead of utilizing it. Strains wV1 and B835 produced acetate, a relatively low proportion of lactate and a high proportion of formate, so these two strains conformed to Group 2 of Shane et al. (1969). No cultures produced significant quantities of ethanol. Propionate did not appear to be metabolized or produced by these strains of $B$. fibrisolvens.

In each culture, the increase in $\mathrm{CO}_{3}{ }^{2-}$ concentration was accompanied by an increase in the proportion of formate in the end-products. This was particularly noted in cultures of 
Table 2. Distribution of carbon from ${ }^{14} \mathrm{CO}_{3}{ }^{2-}$ or $\left[\mathrm{U}^{14} \mathrm{C}\right]$ glucose in cultures of $B$. fibrisolvens

Radioactivities in the various culture components were determined as described in Methods.

\begin{tabular}{|c|c|c|c|c|c|c|}
\hline \multirow[b]{2}{*}{ Strain } & \multirow[b]{2}{*}{ Substrate } & \multirow{2}{*}{$\begin{array}{c}\text { Specific } \\
\text { activity } \\
\text { (d.p.m. } \mu \mathrm{mol}^{-1} \text { ) }\end{array}$} & \multicolumn{3}{|c|}{$\begin{array}{l}\text { Radioactivity recovered } \\
\text { (\% of total) }\end{array}$} & \multirow{2}{*}{$\begin{array}{c}\text { Carbon } \\
\text { incor- } \\
\text { poration } \\
{[\mu \mathrm{g}(\mathrm{ml}} \\
\text { culture })^{-1}\end{array}$} \\
\hline & & & Bacteria & $\begin{array}{l}\text { Growth } \\
\text { medium }\end{array}$ & $\begin{array}{l}\text { Gas } \\
\text { phase }\end{array}$ & \\
\hline wv1 & $\begin{array}{c}{ }^{14} \mathrm{CO}_{3}{ }^{2-} \\
{\left[\mathrm{U}^{14} \mathrm{C}\right] \mathrm{glucose}}\end{array}$ & $\begin{array}{l}55875 \\
45045\end{array}$ & $\begin{array}{l}3 \cdot 9 \\
8 \cdot 5\end{array}$ & $\begin{array}{l}49 \cdot 0 \\
80 \cdot 0\end{array}$ & $\begin{array}{r}46 \cdot 7 \\
4 \cdot 3\end{array}$ & $\begin{array}{r}2 \cdot 1 \\
33 \cdot 9\end{array}$ \\
\hline NOR37 & ${ }^{14} \mathrm{CO}_{3}{ }^{2-}$ & 31481 & $4 \cdot 2$ & $35 \cdot 8$ & $60 \cdot 0$ & $2 \cdot 0$ \\
\hline
\end{tabular}
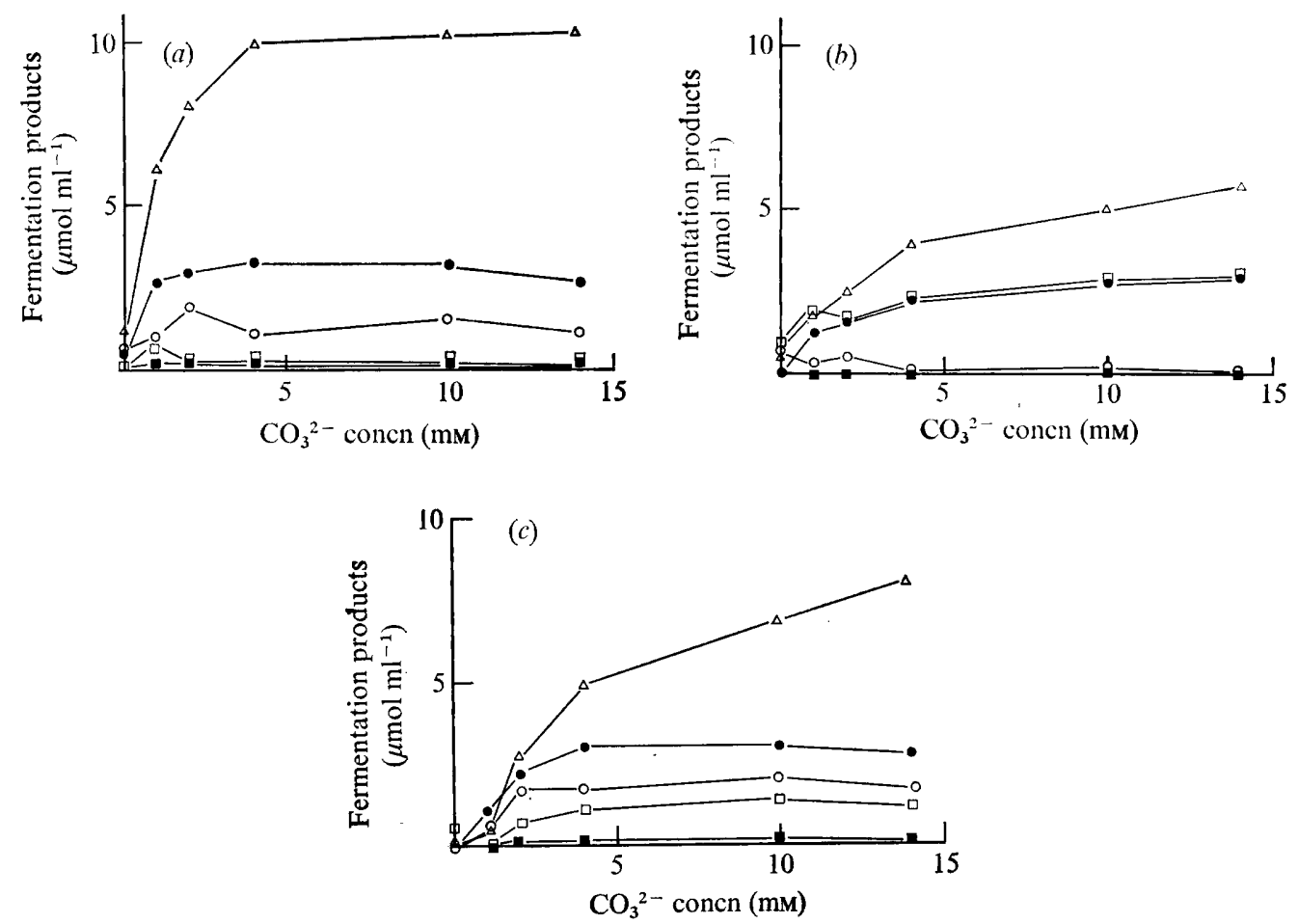

Fig. 1. Effect of $\mathrm{CO}_{3}{ }^{2-}$ concentration on the glucose fermentation products of $B$. fibrisolvens strains: (a) WV1; (b) NOR37; (c) B835. Product concentrations $\left(\mu \mathrm{mol} \mathrm{ml}^{-1}\right)$ have been corrected for levels present in basal media: $O$, acetate; $\bullet$, butyrate; $\square$, lactate; $\boldsymbol{m}$, ethanol; $\triangle$, formate.

B835 and wv1. In wv1 cultures at $\mathrm{CO}_{3}{ }^{2-}$ concentrations above $2 \mathrm{~mm}$, the formate concentration was higher than that expected from the stoicheiometric production of acetate, butyrate and formate from pyruvate. Similar results were obtained for strains NOR37 and

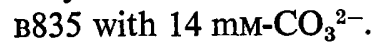

Incorporation of ${ }^{14} \mathrm{CO}_{3}{ }^{2-}$ into fermentation end-products in B. fibrisolvens wV1 and NOR37

After batch growth of $B$. fibrisolvens wv1 and NOR37 for $24 \mathrm{~h}$ at $39^{\circ} \mathrm{C}$ in basal medium containing $4.0 \mathrm{~mm}^{-14} \mathrm{CO}_{3}{ }^{2-}(20 \mu \mathrm{Ci}$ per $40 \mathrm{ml}$ medium$)$, the radioactivities and concentrations of the acid end-products in the media were assayed (Table 3). Butyrivibrio fibrisolvens wv1 produced acetate and little lactate, whilst strain NOR37 used acetate and produced high concentrations of lactate. The distribution of ${ }^{14} \mathrm{C}$ between formate and lactate 
Table 3. Incorporation of ${ }^{14} \mathrm{CO}_{3}{ }^{2-}$ into end-products of fermentation of $\mathrm{B}$. fibrisolvens

\begin{tabular}{|c|c|c|c|c|c|}
\hline \multirow[b]{2}{*}{ Strain } & & \multicolumn{4}{|c|}{ Fermentation end-products } \\
\hline & & Formate & Acetate & Lactate & Butyrate \\
\hline wv1 & $\begin{array}{l}\text { Concn }\left(\mu \mathrm{mol} \mathrm{ml}^{-1}\right) \\
\text { Specific activity* } \\
\text { (d.p.m. } \mu \mathrm{mol}^{-1} \text { ) }\end{array}$ & $\begin{array}{c}3 \cdot 75 \\
33948\end{array}$ & $\begin{array}{l}0.64 \\
-\end{array}$ & $\begin{array}{c}0 \cdot 29 \\
17464\end{array}$ & $\begin{array}{l}3 \cdot 40 \\
-\end{array}$ \\
\hline NOR 37 & $\begin{array}{l}\text { Concn }\left(\mu \mathrm{mol} \mathrm{ml}^{-1}\right) \\
\text { Specific activity* } \\
\left.\text { (d.p.m. } \mu \mathrm{mol}^{-1}\right)\end{array}$ & $\begin{array}{l}4 \cdot 33 \\
4829\end{array}$ & -0.09 & $\begin{array}{l}2 \cdot 20 \\
5166\end{array}$ & $2 \cdot 53$ \\
\hline
\end{tabular}

* Specific activities corrected for the basal levels of formate and lactate in the medium.

differed in the two strains: lactate and formate had similar specific activities in strain NOR37 indicating that the pyruvate pool was the common precursor of both lactate and formate; with strain wv1, the lactate was labelled to a much lesser degree than the formate, indicating that formate may be labelled by additional pathways. Little or no labelling was noted in acetate and butyrate produced by either culture.

\section{Relationship between formate and $\mathrm{CO}_{3}{ }^{2-}$ specific radioactivities in batch cultures of B. fibrisolvens wv1}

Batch cultures $(120 \mathrm{ml})$ of $B$. fibrisolvens wv1 were grown under $\mathrm{N}_{2}$ in $\mathrm{CO}_{3}{ }^{2-}$-limited conditions with ${ }^{14} \mathrm{CO}_{3}{ }^{2-}\left(0.166 \mu \mathrm{Ci} \mathrm{ml}^{-1}\right)$ added at 4 or $10 \mathrm{~mm}$ either early in the exponential phase or early in the stationary phase. The concentrations and radioactivities of formate and $\mathrm{CO}_{3}{ }^{2-}$ were followed. (As a control for measuring ${ }^{14} \mathrm{CO}_{3}{ }^{2-}$ specific activities, a batch of sterile medium containing ${ }^{14} \mathrm{CO}_{3}{ }^{2-}$ was also serially sampled.) Figure 2 shows the results of the experiment using $10 \mathrm{mM}-\mathrm{CO}_{3}{ }^{2-}$. The incorporation of ${ }^{14} \mathrm{C}$ into formate was related to the growth of the culture, but if the ${ }^{14} \mathrm{C}$ was added in stationary phase none was found in formate. When ${ }^{14} \mathrm{CO}_{3}{ }^{2-}$ was added early in exponential phase to a culture containing $4 \mathrm{~mm}-\mathrm{CO}_{3}{ }^{2-}$, formate became labelled to a maximum specific activity of 600 d.p.m. $\mu \mathrm{mol}^{-1}$ although the $\mathrm{CO}_{3}{ }^{2-}$ specific activity was 16000 d.p.m. $\mu \mathrm{mol}^{-1}$. The specific activity of the $\mathrm{CO}_{3}{ }^{2-}$ decreased with time; part of this drop in specific activity may be due to the method used to sample the culture as there was a small decrease in specific activity in the sterile medium used as a control.

\section{Incorporation of $\left[1{ }^{14} C\right]$ acetate into end-products of fermentation in B. fibrisolvens $\mathrm{wv} 1$}

To test for a functional pyruvate synthase in $B$. fibrisolvens wv1, $40 \mathrm{ml}$ medium A containing $10 \mathrm{~mm}-\mathrm{CO}_{3}{ }^{2-}$ and $0.8 \mu \mathrm{Ci}\left[1-{ }^{14} \mathrm{C}\right]$ acetate were inoculated and incubated at $39{ }^{\circ} \mathrm{C}$ for $24 \mathrm{~h}$. The radioactivities and concentrations of fermentation end-products were measured (Table 4). There was only a small net production of lactate in this culture but there was a significant incorporation of radioactivity indicating that acetate was converted to pyruvate which was then reduced to lactate. No activity was incorporated into formate and there was a low incorporation of ${ }^{14} \mathrm{C}$ into butyrate in this culture.

\section{Distribution of $\left[U_{-14}{ }^{14}\right]$ glucose radioactivity among the end-products of fermentation in B. fibrisolvens wv1}

To test whether pyruvate or acetate added to the medium would diminish the requirement for $\mathrm{CO}_{3}{ }^{2-}$, batch cultures of $B$. fibrisolvens wv1 were grown to early stationary phase in

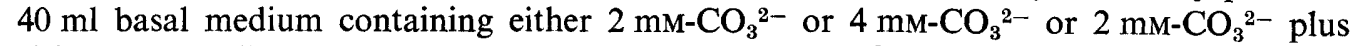
either $2 \mathrm{~mm}$-sodium pyruvate or $2 \mathrm{~mm}$-sodium acetate; [U-14 C] per flask. The radioactivity in the acid end-products in the bacteria-free culture media (Table 5) varied between 58 and $77 \%$ of the label in the added glucose. Added acetate 


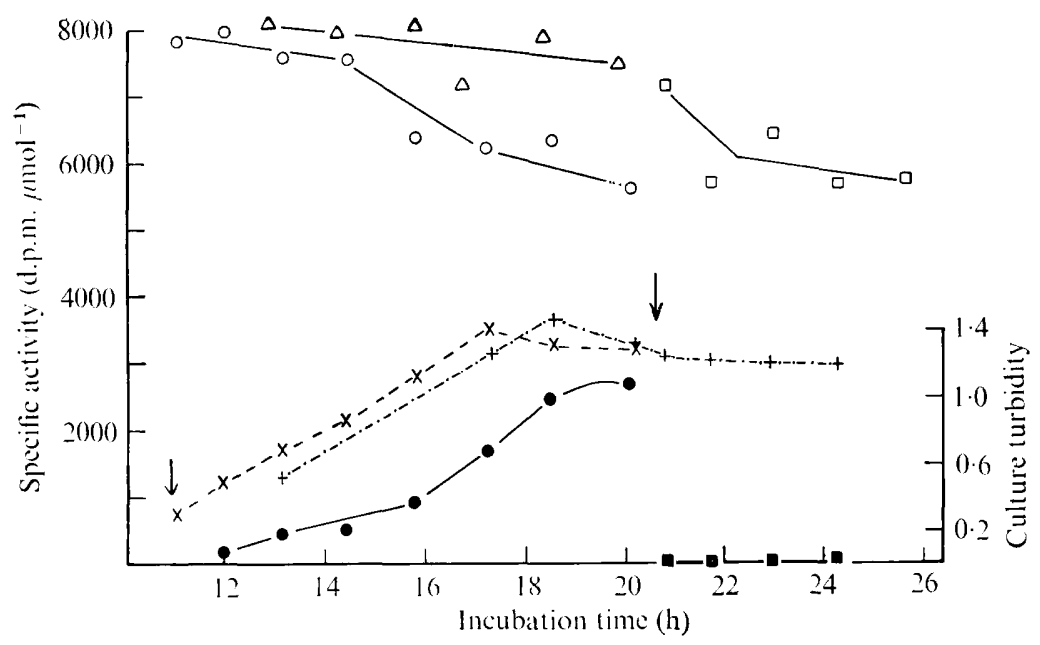

Fig. 2. Effect of growth phase on the specific activities of formate and $\mathrm{CO}_{3}{ }^{2-}$ in cultures of $B$. fibrisolvens wv1. The $\mathrm{CO}_{3}{ }^{2-}$ concentration in the medium was $10 \mathrm{mM}$ and ${ }^{14} \mathrm{CO}_{3}{ }^{2-}$ was added in early-exponential or early-stationary phase. Specific activities when ${ }^{14} \mathrm{CO}_{3}{ }^{2-}$ was added to a growing culture: $\mathrm{O}, \mathrm{CO}_{3}{ }^{2-} ; \boldsymbol{Q}$, formate. Specific activities when ${ }^{14} \mathrm{CO}_{3}{ }^{2-}$ was added to a culture in stationary phase: $\square, \mathrm{CO}_{3}{ }^{2-} ; \square$, formate. Specific activity when ${ }^{14} \mathrm{CO}_{3}{ }^{2-}$ was added to an uninoculated culture vessel: $\triangle, \mathrm{CO}_{3}{ }^{2-} . \times,+$, Culture turbidity; arrows indicate the times at which ${ }^{14} \mathrm{CO}_{3}{ }^{2-}$ was added.

Table 4. Incorporation of $\left[1-{ }^{14} \mathrm{C}\right]$ acetate into end-products of fermentation of B. fibrisolvens wv1

\begin{tabular}{llcccc} 
& & \multicolumn{3}{c}{ Fermentation end-products } \\
\cline { 3 - 6 } Formate & Acetate & Lactate & Butyrate \\
Concn $\left(\mu \mathrm{mol} \mathrm{ml}^{-1}\right)$ & Total & 7.50 & 4.80 & 0.85 & $2 \cdot 88$ \\
& Net & 5.60 & 0.65 & 0.07 & 2.88 \\
$\begin{array}{c}\text { Specific activity } \\
\left.\text { (d.p.m. } \mu \mathrm{mol}^{-1}\right)\end{array}$ & & 0 & 9397 & $2574^{*}$ & 176
\end{tabular}

(d.p.m. $\mu \mathrm{mol}^{-1}$ )

* Specific activity corrected for the basal level of lactate in the medium.

Table 5. Distribution of $\left[U-{ }^{14} C\right]$ glucose radioactivity among the end-products of fermentation in B. fibrisolvens wv1

\begin{tabular}{|c|c|c|c|c|c|c|}
\hline \multirow{2}{*}{$\begin{array}{l}\text { Addition to basal } \\
\text { medium }\end{array}$} & \multirow{2}{*}{$\begin{array}{l}\text { Growth } \\
\text { rate } \\
\left(\mathrm{h}^{-1}\right)\end{array}$} & \multirow{2}{*}{$\begin{array}{c}\text { Glucose } \\
\text { used } \\
\left(\mu \mathrm{mol} \mathrm{ml}^{-1}\right)\end{array}$} & \multicolumn{4}{|c|}{ Specific activity [d.p.m. $(\mu \mathrm{mol} \mathrm{C})^{-1}$ ] } \\
\hline & & & Formate & Acetate & Lactate & Butyrate \\
\hline $\begin{array}{l}2 \mathrm{mM}-\mathrm{CO}_{3}{ }^{2-} \\
4 \mathrm{mM}^{-} \mathrm{CO}_{3}{ }^{2-} \\
2 \mathrm{~mm}-\mathrm{CO}_{3}{ }^{2-}+\end{array}$ & $\begin{array}{l}0 \cdot 20 \\
0 \cdot 30 \\
0 \cdot 20\end{array}$ & $\begin{array}{l}4 \cdot 22 \\
5 \cdot 76 \\
4 \cdot 40\end{array}$ & $\begin{array}{l}1693 \\
1365 \\
1595\end{array}$ & $\begin{array}{l}614 \\
402 \\
464\end{array}$ & $\begin{array}{r}1065 \\
835 \\
1004\end{array}$ & $\begin{array}{l}1521 \\
1685 \\
1359\end{array}$ \\
\hline $\begin{array}{c}2 \mathrm{~mm} \text {-pyruvate } \\
2 \mathrm{mM}-\mathrm{CO}_{3}{ }^{2-}+ \\
2 \mathrm{mM} \text {-acetate }\end{array}$ & 0.24 & 4.94 & 1147 & 346 & 519 & 1408 \\
\hline
\end{tabular}

Specific activity of the substrate glucose was 1794 d.p.m. $(\mu \mathrm{mol} \mathrm{C})^{-1}$. 
stimulated the growth rate and glucose utilization but less than did an equimolar addition of $\mathrm{CO}_{3}{ }^{2-}$. The specific activities of the end-products showed that butyrate was derived mainly from glucose and partly from a non-radioactive precursor, probably acetate present in the basal medium.

Formate and lactate specific activities were depressed by adding extra $\mathrm{CO}_{3}{ }^{2-}$ or acetate. Adding pyruvate had no effect on lactate specific activity and caused only a small depression in formate specific activity.

\section{DISCUSSION}

Van Gylswyk (1976) has shown, using a Group 1 strain of $B$. fibrisolvens, that ${ }^{14} \mathrm{CO}_{2}$ can exchange with the pyruvate carboxyl carbon leading to production of labelled formate. Using a Group 2 strain (Wv1) we found that uptake of ${ }^{14} \mathrm{CO}_{3}{ }^{2-}$ into formate was growth dependent and, in the batches grown with $10 \mathrm{mM}-\mathrm{CO}_{3}{ }^{2-}$, the greater growth was accompanied by higher specific activitities in formate although the specific activity of the added $\mathrm{CO}_{3}{ }^{2-}$ was less than half that of the batch grown with $4 \mathrm{~mm}-\mathrm{CO}_{3}{ }^{2-}$. The study of changes in $\mathrm{CO}_{3}{ }^{2-}$ specific activity showed that as the formate specific activity increased so the $\mathrm{CO}_{3}{ }^{2-}$ specific activity decreased. Examination of a control vessel in which samples of uninoculated media were assayed showed that part of this decrease was associated with the technique whereby medium removed was replaced with nitrogen. The decrease in $\mathrm{CO}_{3}{ }^{2-}$ specific activity was, however, consistent with an exchange reaction.

Carbon dioxide may also enter pyruvate by way of pyruvate synthase and in strain wv1 $\left[1-{ }^{14} \mathrm{C}\right]$ acetate was incorporated into lactate confirming that pyruvate synthase must be operating. Van Gylswyk (1976) found that pyruvate synthase operated in a Group $1 B$. fibrisolvens.

If pyruvate is cleaved by pyruvate formate lyase then the formate and lactate produced from labelled pyruvate should be equally labelled. Group 1 B. fibrisolvens NOR 37, grown in the presence of ${ }^{14} \mathrm{CO}_{3}{ }^{2-}$, produced formate and lactate with equal specific activities indicating that pyruvate was a common precursor and confirming a similar result of Van Gylswyk (1976). In a similar experiment, however, using the Group 2 strain wv1, formate was more highly labelled than was lactate, indicating that formate was derived from ${ }^{14} \mathrm{CO}_{3}{ }^{2-}$ by an additional path. Possibly in the Group $2 \mathrm{~B}$. fibrisolvens $\mathrm{CO}_{2}$ acts directly as an electron acceptor in a manner similar to that reported by Miller \& Wolin (1973) for Ruminococcus albus. Miller (1975) reported that in R. albus, R. flavefaciens and B. fibrisolvens, formate did not arise directly by cleavage of pyruvate.

With strain $\mathrm{Wvl}$, grown in the presence of $\left[\mathrm{U}-{ }^{14} \mathrm{C}\right]$ glucose, additional pyruvate or acetate could not replace the requirement for $\mathrm{CO}_{2}$. Van Gylswyk (1976) showed that in a Group 1 $B$. fibrisolvens, external pyruvate could act as an electron acceptor and was rapidly converted to lactate. In strain wv1, external pyruvate did not enter the pool from which lactate was formed. It did, however, appear to be partly metabolized to acetate and thence to butyrate since the specific activities of these end-products were reduced. Added acetate reduced the specific activities of lactate and formate, the former presumably by means of the pyruvate synthase reaction, but it is not obvious how it would reduce the formate specific activity unless acetate carbon was converted to $\mathrm{CO}_{2}$ by the operation of an acetate- $\mathrm{CO}_{2}$ exchange (Ljungdahl \& Wood, 1969) or by a tricarboxylic acid cycle pathway, reducing the specific activity of the $\mathrm{CO}_{2}$ pool and thus the specific activity of formate. In each of these experiments there was evidence that butyrate was formed mainly from radioactive glucose and only partly from acetate present in the medium. Thus the Group 2 strain used in this study differed from the Group 1 strain used by Van Gylswyk (1976) which produced butyrate predominantily from added acetate rather than acetate derived from substrate glucose.

The increases in molar growth yields from glucose with strains wv1 and NOR37 with increasing $\mathrm{CO}_{3}{ }^{2-}$ concentrations arose from concomitant increases in growth rate as, at 
higher growth rates, less energy is diverted into maintenance functions (Pirt, 1965). With B835 there were only small changes in molar growth yield and growth rate with increasing $\mathrm{CO}_{3}{ }^{2-}$ concentration as its $\mathrm{CO}_{3}{ }^{2-}$ requirement was met at low levels; some other but unknown limitation was, however, affecting its growth.

Despite differences in the metabolic pathways which operate in Group 1 and Group 2 B. fibrisolvens, $\mathrm{CO}_{3}{ }^{2-}$ can stimulate growth of both groups by acting as an electron acceptor. In the Group 1 bacteria, $\mathrm{CO}_{3}{ }^{2-}$ is fixed by the reductive pyruvate synthase reaction producing pyruvate which can either be further reduced to lactate or split to acetate and formate. In the Group 2 bacteria, $\mathrm{CO}_{3}{ }^{2-}$ is reduced directly to formate. In both groups of bacteria, $\mathrm{H}_{2}$ can be produced but in pure cultures the hydrogenase reaction may become rate-limiting as $\mathrm{H}_{2}$ accumulates, hence the requirement for formate production as an alternative means of regenerating oxidized co-factors.

We are grateful to Miss Shona Neil and Mr J. Matheson for technical assistance. B.D.W.J. is grateful to Dr P. N. Hobson for the hospitality of his laboratory.

\section{REFERENCES}

Asmundson, R. V. (1974). Growth of Streptococcus bovis and a Butyrivibrio in batch and continuous culture and the relationship of molar growth yield to intermicrobial competition. M.Sc. thesis, Massey University, Palmerston North, New Zealand.

Barker, S. A. \& Somers, P. J. (1966). A spectrophotometric method for the determination of formic acid in the periodate oxidation of carbohydrates. Carbohydrate Research 3, 220-224.

Bové, J. \& Raveux, R. (1957). La séparation et la détermination des acides carboxyliques de $C_{1}$ à $C_{6}$ par chromatographie de partage sur colonne de silice. II. Nouvelle technique proposée. Bulletin de la Société chimique de France 3, 376-387.

Bryant, M. P. \& Small, N. (1956). The anaerobic monotrichous butyric acid-producing curved rod-shaped bacteria of the rumen. Journal of Bacteriology 72, 16-21.

Caldwell, D. R. \& Bryant, M. P. (1966). Medium without rumen fluid for nonselective enumeration and isolation of rumen bacteria. Applied Microbiology 14, 794-801.

Caldwell, D. R., Keeney, M. \& Van Soest, P. J. (1969). Effects of carbon dioxide on growth and maltose fermentation by Bacteroides amylophilus. Journai of Bacteriology 98, 668-676.

Conway, E. J. (1957). Microdiffusion Analysis and Volumetric Error. London: Crosby Lockwood.

Dawes, E. A., McGill, D. J. \& Midgley, M. (1971). Methods in Microbiology 6A, 53-215.

Dehority, B. A. (1971). Carbon dioxide requirement of various species of rumen bacteria. Journal of Bacteriology 105, 70-76.

Fell, B. F., Kay, M., Whitelaw, F. G. \& Boyne, R. (1968). Observations on the development of ruminal lesions in calves fed on barley. Research in Veterinary Science 9, 458-466.

Howlett, M. R., Mountfort, D. O., Turner, K. W. \& Ronerton, A. M. (1976). Metabolism and growth yields in Bacteroides ruminicola strain $\mathrm{B}_{1} 4$. Applied and Environmental Microbiology 32, 274-283.

Kaplan, N. O. \& Ciotti, M. M. (1957). Enzymatic determination of ethanol. Methods in Enzymology 3, 253-255.
Latham, M. J \& Legakis, N. J. (1976). Cultural factors influencing the utilization or production of acetate by Butyrivibrio fibrisolvens. Journal of General Microbiology 94, 380-388.

Latham, M. J., Sutton, J. D. \& Sharpe, M. E. (1974). Fermentation and micro-organisms in the rumen and the content of fat in the milk of cows given low roughage rations. Journal of Diry Science 57, 803-810.

LJUnGDahl, L. G. \& Wood, H. G. (1969). Total synthesis of acetate from $\mathrm{CO}_{2}$ by heterotrophic bacteria. Annual Review of Microbiology 23, 515-535.

Miller, T. L. (1975). Pyruvate cleavage reactions of hydrogen and formate producing rumen bacteria. Abstracts. Annual Meeting of the American Society for Microbiology, Abstract 20, p. 150.

Miller, T. L. \& Wolin, M. J. (1973). Formation of hydrogen and formate by Ruminococcus albus. Journal of Bacteriology 116, 836-846.

Morley, G., Dawson, A. \& Marks, D. V. (1968). Manual and autoanalyser methods for measuring blood glucose using quaiacum and glucose oxidase. Proceedings of the Association of Clinical Biochemists 5, 42-45.

PIRT, S. J. (1965). The maintenance energy of bacteria in growing cultures. Proceedings of the Royal Society B163, 224-231.

Shane, B. S., Gouws, L. \& Kistner, A. (1969). Cellulolytic bacteria occurring in the rumen of sheep conditioned to low-protein teff hay. Journal of General Microbiolo $y$ y 55, 445-457.

VAN GylswyK, N. O. (1970). The effect of supplementing a low-protein hay on the cellulolytic bacteria in the rumen of sheep and on the digestibility of cellulose and hemicellulose. Journal of Agricultural Scicnce, Cambridge 74, 169-180.

VAN GylswyK, N. O. (1976). Some aspects of the metabolism of Butyrivibrio fibrisolvens. Journal of General Microbiology 97, 105-111.

Wright, D. E. (1960). The metabolism of carbon dioxide by Streptococcus bovis. Journal of General Microbiology 22, 713-725. 